\title{
UNIDADES CLIMÁTICAS DO TRIÂNGULO MINEIRO/ALTO PARANAÍBA
}

\author{
NOVAIS, Giuliano Tostes - giuliano.novais@ueg.br \\ Universidade Estadual de Goiás / UEG \\ BRITO, Jorge Luís Silva - jbrito@ufu.br \\ Universidade Federal de Uberlândia / UFU
}

SANCHES, Fabio de Oliveira - fsanches.73@gmail.com
Universidade Federal de Juiz de Fora / UFJF

\begin{abstract}
RESUMO: A classificação climática é considerada um estudo básico para auxílio no planejamento ambiental e econômico, definindo o clima em diversas regiões. Os modelos de classificação permitem uma compreensão sintética das principais características climáticas de uma região. Este trabalho propõe uma nova abordagem de mapeamento das unidades climáticas para a mesorregião do Triângulo Mineiro/Alto Paranaíba (MG), considerando a temperatura média do mês mais frio, a variação na precipitação pluviométrica, a quantidade de meses secos, as passagens de frentes frias e possibilidade de formação de geadas. Esse sistema de classificação climática possui uma hierarquia, podendo ser dividido em domínios, subdomínios, tipos, subtipos e meso/topoclimas. Para determinar as unidades climáticas foram utilizados dados de sete estações do Instituto Nacional de Meteorologia (INMET) e 55 pluviômetros da Agência Nacional de Águas (ANA). Três domínios climáticos foram identificados na área de estudo: Tropical, Tropical Ameno e Subtropical; esses são subdivididos em subdomínios (semiúmido e semiseco), tipos (meridional e setentrional) e subtipos. A definição das unidades climáticas do Triângulo Mineiro/Alto Paranaíba fornece importantes subsídios para novos estudos regionais em climatologia (climatologia de detalhe). Esse novo sistema de classificação climática é aperfeiçoado, devido a grande quantidade de dados históricos, podendo ser usado em análises ambientais, didáticas e agrícolas.
\end{abstract}

PALAVRAS-CHAVE: Classificação climática, temperatura média do mês mais frio, evapotranspiração potencial, sistemas atmosféricos.

\section{CLIMATIC UNITS OF THE TRIÂNGULO MINEIRO / ALTO PARANAÍBA}

ABSTRACT: Climate classification is considered a basic study for aiding environmental and economic planning, defining the climate on several regions. The classification models allow a synthetic understanding of the main characteristics of a region. This work proposes a new mapping of the climatic units for the Triângulo Mineiro / Alto Paranaíba mesoregion, in the state of Minas Gerais, Brazil, considering the average temperature of the coldest month, the variation in rainfall, the number of dry months, the occurrence of cold fronts and possibility of frost. The proposed climate classification system has a hierarchy divided into domains, subdomains, types, subtypes and meso / topoclimas. To determine the climatic units were used data from seven stations of the National Institute of Meteorology (INMET) and 55 rain gauges from the National Water Agency (ANA). Three climatic domains were identified on the study area: Tropical, Mild Tropical and Subtropical; these are subdivided into subdomains (semi-humid and semi-dry), types (southern and northern), and subtypes. The definition of the climatic units of the Triângulo Mineiro / Alto Paranaíba provides important subsidies for new regional studies in climatology (climatology of detail). This new climate classification system is improved due to the large amount of historical data, and can be used in environmental, didactic and agricultural analysis.

KEYWORDS Climate classification, average temperature of the coldest month, potential evapotranspiration, atmospheric systems. 


\section{INTRODUÇÃO}

A Climatologia tem como um dos grandes desafios sistematizar o maior número de dados meteorológicos e climáticos e convertê-los em medidas estatísticas que deem parâmetros para o agrupamento das características da atmosfera sobre os distintos lugares.

Neste sentido, Terassi (2013) afirma que a classificação climática é importante por definir os climas de diferentes regiões levando em consideração os diferentes elementos climáticos simultaneamente, sendo considerado um estudo básico para auxiliar no planejamento ambiental e econômico. Os métodos classificatórios, cada um com suas especificidades, permitem uma compreensão sintética das características climáticas de determinado espaço.

Em qualquer lugar da Terra, a quantidade de energia solar recebida em um dia dependerá, basicamente, de três fatores: 1) o ângulo com que os raios solares incidem sobre a superfície; 2) o tempo de duração da exposição a estes raios (fotoperíodo) e, 3) a cobertura de nuvens. Esses fatores variam com a latitude e com a mudança das estações do ano, que faz variar a trajetória do Sol no firmamento (STRAHLER, 1989).

Segundo Koeppen (1948), devido às elevadas temperaturas nas regiões intertropicais (principalmente próximas da linha do equador), o homem se torna tão sensível a diferenças térmicas que sente frio quando a temperatura fica abaixo de $22^{\circ} \mathrm{C}$; os europeus também experimentam essa sensibilidade depois de uma estadia de poucos meses sobre o clima tropical. Populações do continente africano sentem frio a partir da isoterma de $23^{\circ} \mathrm{C}$. Os esforços de trabalhos (físicos e mentais) cansam mais nas regiões intertropicais comparados com regiões fora dos trópicos. Koeppen (1948) também afirma que o calor é um fator muito importante para o desenvolvimento de certos parasitas e vermes tropicais, e o limite de temperatura para esse crescimento é a isoterma de $18^{\circ} \mathrm{C}$. Já Mendonça (2003) cita casos de dengue relacionados à temperatura alta na região tropical:

A distribuição dos mosquitos, a frequência de suas picadas e o período de incubação do vírus são afetados pela temperatura, pluviosidade e velocidade do vento; por exemplo, com uma temperatura de $27^{\circ} \mathrm{C}$, o período de incubação é de dez dias, no entanto a $37^{\circ} \mathrm{C}$ esse período passa a ser de sete dias. Além disso, a intermitência das chuvas no final da estação de verão e os ventos calmos acentuam a proliferação e atuação do vetor (2003, p. 210).

Para Novais (2017), a delimitação dos climas zonais é baseada na temperatura média do mês mais frio (TMMMF). A distribuição de energia ocasionada pela radiação solar na troposfera se diferencia latitudinalmente, tornando a temperatura o principal elemento climático nessa escala. Esse parâmetro também demonstra o máximo deslocamento de massas polares atingindo as regiões de baixas latitudes. Com poucas exceções, as frentes frias não atingem regiões de clima tórrido. No caso das regiões de clima moderado, frio e polar, essa condição de temperatura influencia na quantidade de dias frios, ou até mesmo, de dias com cobertura de neve e congelamento total do solo.

O clima zonal tem origem em sua própria zona climática, e não é fixo, podendo ultrapassar seus limites, alterando as condições térmicas em outras 
zonas climáticas. A exceção é o Clima Zonal Polar que é restrito a Zona Climática Polar, por influência da baixa incidência solar (NOVAIS, 2017).

Novais (2017), ainda esclarece que no Clima Zonal Tórrido a temperatura de $22,5^{\circ} \mathrm{C}$ no mês mais frio faria o limite com o Clima Zonal Quente, devido a grande sensibilidade ao frio de populações que vivem nessa zona climática. Entre o Clima Zonal Quente e o Clima Zonal Moderado foi estabelecida a isoterma de $15^{\circ} \mathrm{C}$ para delimitar os dois climas; essa temperatura correlaciona com pelo menos um dia de geada no mês mais frio, e também afasta a possibilidade de desenvolvimento de qualquer enfermidade tropical. Já a isoterma de $0^{\circ} \mathrm{C}$ para a temperatura média do mês mais frio (TMMMF) separa o Clima Zonal Moderado do Clima Zonal Frio; que segundo Koeppen (1948), para os norte-americanos essa temperatura é suficientemente baixa para produzir uma cobertura de neve que se estende por várias semanas na estação de inverno. O Clima Zonal Polar tem o limite em sua TMMMF de $-15^{\circ} \mathrm{C}$, valor que propicia um congelamento do solo na maior parte do ano.

Os sistemas meteorológicos influenciam diretamente em todos os climas ao redor do mundo. A Zona de Convergência Intertropical (ZCIT) é considerada o sistema mais importante gerador de precipitação sobre a região equatorial dos oceanos Atlântico, Pacífico e Índico, assim como sobre áreas continentais adjacentes (CAVALCANTI et al, 2009).

Acompanhando o ciclo anual das chuvas no continente sul americano, uma das características mais marcantes do clima tropical durante o verão é a presença de uma banda de nebulosidade e chuvas com orientação noroestesudeste, a qual se estende desde a Amazônia até o Sudeste do Brasil e, frequentemente, sobre o oceano Atlântico subtropical. Para Cavalcanti et al (2009), essa característica climatológica que se associa a um escoamento convergente de umidade na baixa troposfera, convencionou-se chamar de Zona de Convergência do Atlântico Sul (ZCAS).

Este artigo tem como objetivo a proposição de uma nova abordagem de mapeamento das unidades climáticas para a mesorregião do Triângulo Mineiro/Alto Paranaíba, no estado de Minas Gerais (Mapa 1), considerando a temperatura média do mês mais frio, a variação na precipitação pluviométrica, a quantidade de meses secos, as passagens de frentes frias e possibilidade de formação de geadas. As cores no Mapa 1 servem apenas para diferenciar 0 limite dos municípios na mesorregião estudada. 


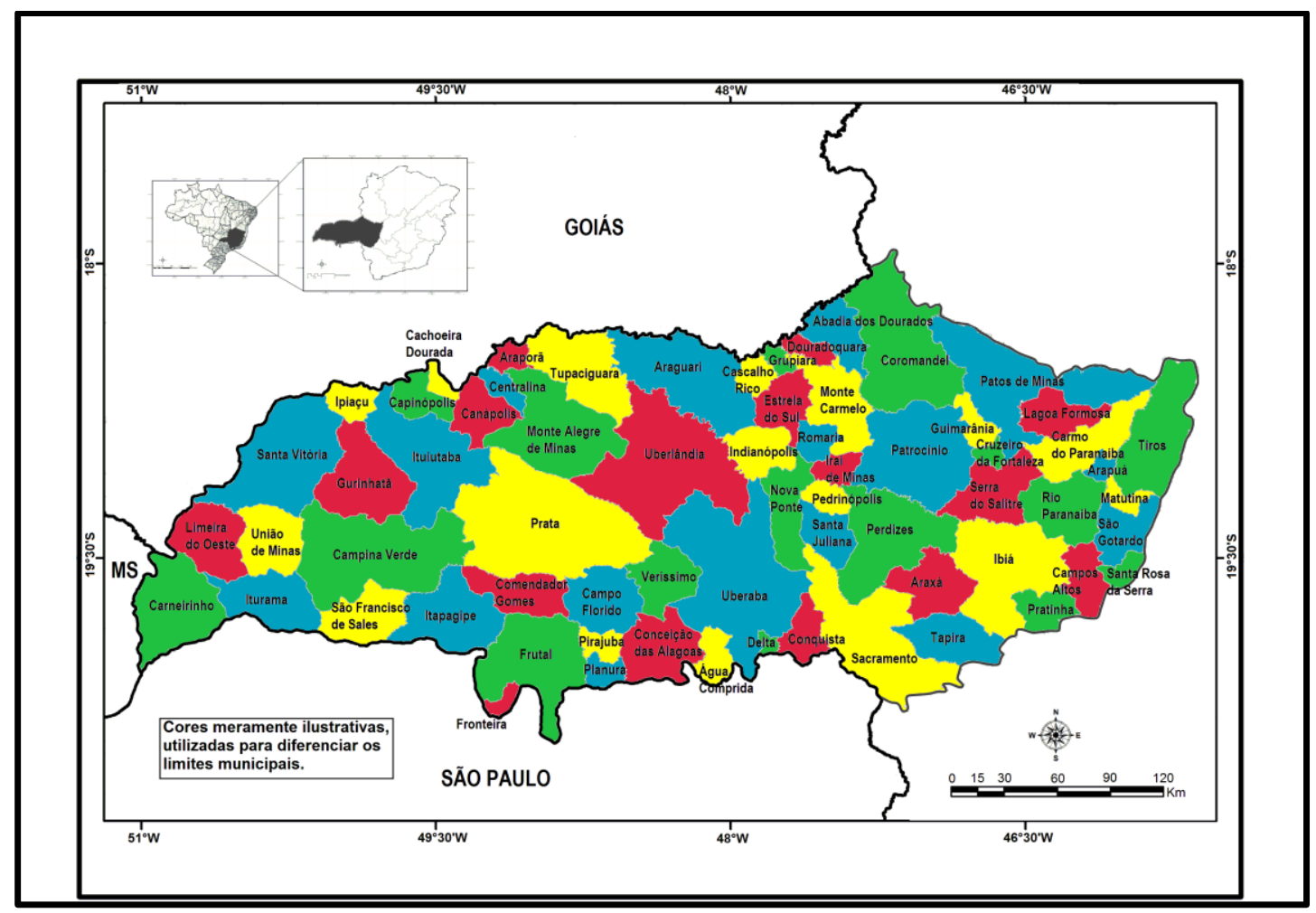

Mapa 1 - Localização da área de estudo - Municípios da mesorregião do Triângulo Mineiro/Alto Paranaíba, estado de Minas Gerais.

\section{MATERIAIS E MÉTODOS}

A proposta de classificação climática desse trabalho segue o modelo proposto por Novais (2017), sendo que o Clima Zonal está na primeira hierarquia. A temperatura média do mês mais frio (TMMMF) foi utilizada para delimitar os climas zonais e alguns domínios climáticos. A baixa temperatura influencia na quantidade de dias com geada na mesorregião.

Os Domínios Climáticos estão na segunda hierarquia da classificação climática, e podem pertencer a mais de um clima zonal. A TMMMF é de suma importância na sua caracterização, mas o que mais influencia são os sistemas meteorológicos como: zonas de convergência de ventos e umidade, frentes frias, formação de geada, etc.

Os domínios são divididos em subdomínios, com critério de duração dos meses secos, podendo variar de: úmido (zero a três meses secos); semiúmido (quatro a cinco meses secos); semiseco (seis a sete meses secos); e seco (oito a onze meses secos). O domínio Árido possui 12 meses secos e não tem subdomínios (esse domínio climático aparece no interior do polígono das secas no sertão nordestino brasileiro).

A metodologia para determinação de mês seco consiste na diferença entre a precipitação pluviométrica e a evapotranpiração potencial (ETP). Se a precipitação for menor que a ETP, o mês é seco. Para o cálculo da ETP foi utilizada a planilha de balanço hídrico climatológico elaborada por Sentelhas et 
al (1998), a partir do método proposto por Thorntwaite\&Mather (1955), tendo a latitude e a temperatura média como parâmetros meteorológicos.

Seguindo a hierarquia dessa classificação as próximas unidades climáticas são os tipos, que se manifestam pela localização dentro dos subdomínios, e são influenciados por sistemas meteorológicos que ali atuam e modificam o tempo drásticamente, e também pela proximidade do oceano. Os tipos climáticos têm a sua localização vinculada a um subdomínio climático de origem, em território brasileiro, podendo ser: setentrional, meridional (por exemplo: área de maior incursão de sistemas meteorológicos como frentes frias e geadas esporádicas), central, amazônico (de influência da Floresta Amazônica), nordestino, litorâneo (planície litorânea até escarpas de planaltos ou serras - em alguns locais podendo chegar a centenas de quilômetros), etc.

O Quadro 1 demonstra a classificação climática adotada para o território brasileiro e subdividida da segunda a quarta hierarquia (domínios climáticos, subdomínios climáticos e tipos climáticos).

Quadro 1 - Unidades climáticas brasileiras.

\begin{tabular}{|c|c|c|}
\hline DOMÍNIO CLIMÁTICO & SUBDOMÍNIO CLIMÁTICO & TIPO CLIMÁTICO \\
\hline Equatorial & $\begin{array}{l}\text { Úmido } \\
\text { Semiúmido } \\
\text { Semiseco } \\
\text { Seco }\end{array}$ & $\begin{array}{l}\text { Amazônico } \\
\text { Litorâneo } \\
\text { Nordestino }\end{array}$ \\
\hline Equatorial Ameno & $\begin{array}{l}\text { Úmido } \\
\text { Semiúmido }\end{array}$ & Amazônico \\
\hline Tropical & $\begin{array}{l}\text { Úmido } \\
\text { Semiúmido } \\
\text { Semiseco } \\
\text { Seco }\end{array}$ & $\begin{array}{l}\text { Central } \\
\text { Litorâneo } \\
\text { Meridional } \\
\text { Nordestino } \\
\text { Ocidental } \\
\text { Setentrional }\end{array}$ \\
\hline Tropical Ameno & $\begin{array}{l}\text { Úmido } \\
\text { Semiúmido } \\
\text { Semiseco } \\
\text { Seco }\end{array}$ & $\begin{array}{l}\text { Central } \\
\text { Litorâneo } \\
\text { Meridional } \\
\text { Nordestino } \\
\text { Ocidental } \\
\end{array}$ \\
\hline Subtropical & $\begin{array}{l}\text { Úmido } \\
\text { Semiúmido } \\
\text { Semiseco }\end{array}$ & $\begin{array}{l}\text { Litorâneo } \\
\text { Meridional } \\
\text { Setentrional }\end{array}$ \\
\hline Subtropical Frio & Úmido & $\begin{array}{l}\text { Meridional } \\
\text { Setentrional }\end{array}$ \\
\hline Árido & - & Nordestino \\
\hline
\end{tabular}

Para esse trabalho, temperaturas mínimas absolutas abaixo de $3,5^{\circ} \mathrm{C}$ são consideradas propícias para a formação de geada e os dados das estações do INMET na região já acusaram esse valor em dezenas de anos num período climatológico (30 anos). Esse fenômeno meteorológico é um dos parâmetros para delimitação do tipo meridional em domínios mais quentes, no território brasileiro. Foi utilizado o mapa de passagem de frentes frias e ocorrência de 
geada e neve no território brasileiro (Novais, 2016), com base nas informações de Assad (2004), Cavalcanti (2009) e Fuentes (2009) para verificar se o Triângulo Mineiro/Alto Paranaíba enquadram-se nesse tipo climático.

Os subtipos climáticos também são delimitados por sua localização, mas em escala menor - dentro de estados ou regiões, recebendo, muitas vezes, nomenclaturas de cunho geomorfológico (morfoesculturas e formas de relevo); mas também por localizações coincidentes com estados e mesorregiões geográficas oficias. Na área de estudo, muitos subtipos climáticos foram delimitados com a ajuda do mapa geomorfológico do Triângulo Mineiro, elaborado por Baccaro et al (2001).

Numa última categoria hierárquica aparecem os mesoclimas e/ou topoclimas (meso/topoclimas), delimitados por elementos geomorfológicos de pequenos táxons (como geossistemas, geótopos e geofácies), acidentes geográficos de grande destaque na paisagem e também por grandes aglomerações urbanas (metrópoles). Por existirem inúmeros locais possíveis para a delimitação dos meso/topoclimas na paisagem continental brasileira, esse nível climático tem a possibilidade de ser estudado por muitos anos ainda, tanto regionalmente, quanto localmente.

Para determinar as subdivisões climáticas do Triângulo Mineiro/Alto Paranaíba foram utilizados dados de temperaturas médias mensais e precipitações pluviométricas médias mensais de sete estações climatológicas do Instituto Nacional de Meteorologia (INMET) e 55 pluviômetros da Agência Nacional de Águas (ANA) distribuídos por toda mesorregião e também fora dela (MG, GO, MS e SP), auxiliando nas interpolações de valores (Mapa 2). Foram selecionados os locais com registros climatológicos acima de 30 anos. Nos dados das séries históricas do INMET e da ANA, os meses que não apresentaram dados foram descartados, deixando apenas os dados válidos para elaboração da média anual do período. Essa metodologia foi considerada mais aceitável, pois não elimina totalmente o ano de medições. Foi utilizado o modelo de interpolação spline para elaboração do mapa pluviométrico e de quantidade de meses secos. O algoritmo spline consiste em um método de interpolação de dados que estima valores usando uma função matemática, de Função de Base Radial, com condição de minimização dos desvios entre valores observados e calculados, ao mesmo tempo, em que promove a suavização da superfície obtida utilizando os pontos de entrada (LEITE, 2007; MARCUZZO et al., 2010). 


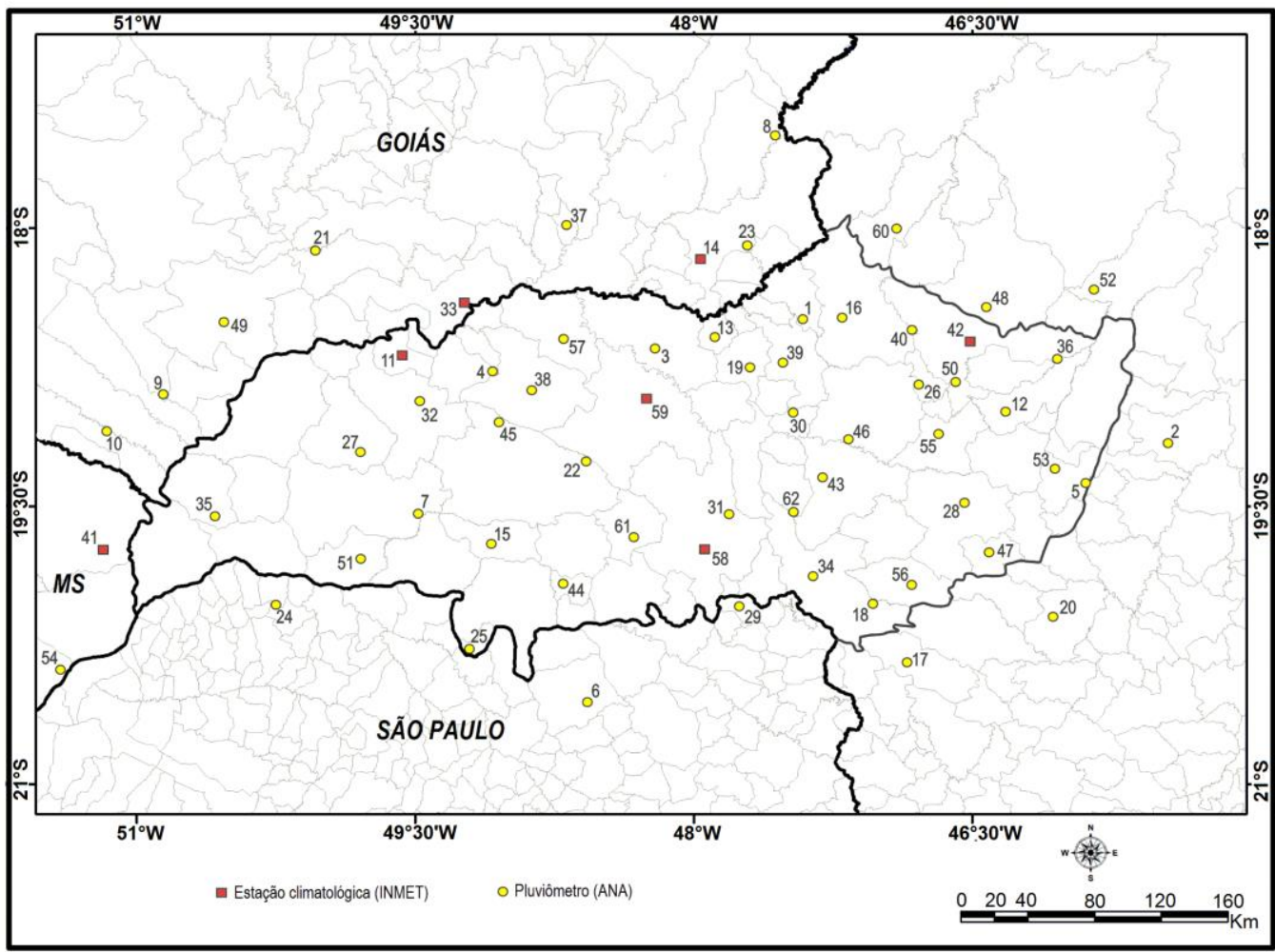

\begin{tabular}{|c|c|c|c|c|c|}
\hline $\mathrm{N}^{\circ}$ & Localidade/Município (Estado) & Entidade & $\mathrm{N}^{\circ}$ & Localidade/Município (Estado) & Entidade \\
\hline 1 & Abadia dos Dourados (MG) & ANA & 32 & Ituiutaba (MG) & ANA \\
\hline 2 & Abaeté (MG) & ANA & 33 & Itumbiara (GO) & INMET \\
\hline 3 & Araguari (MG) & ANA & 34 & Lagoa Sacramento (MG) & ANA \\
\hline 4 & Ayantiguara Canáp olis (MG) & ANA & 35 & Limeira d'Oeste (MG) & ANA \\
\hline 5 & Barra do FunchalSão Gotardo (MG) & ANA & 36 & Major Porto/Patos de Mmas (MG) & ANA \\
\hline के & Barretos (SP) & ANA & 37 & Marzagão (GO) & ANA \\
\hline 7 & Campina Verde (MG) & ANA & 38 & Monte Alegre de Mmas (MG) & ANA \\
\hline 8 & Campo Alegre de Goiás (GO) & ANA & 39 & Monte Carmelo (MG) & ANA \\
\hline 2 & Campo Alegre Cachoeira Alta (GO) & ANA & 40 & Pântano/Coromandel (MG) & ANA \\
\hline 10 & Canastral'alá(GO) & ANA & 41 & Paranaiba (MS) & INMET \\
\hline 11 & Capinópolis (MG) & INMET & 42 & Patos de Minas (MG) & INMET \\
\hline 12 & Carmo do Paranaiba (MG) & ANA & 43 & Perdizes (MG) & ANA \\
\hline 13 & Cascalho Rico (MG) & ANA & 44 & Rirajuba (MG) & ANA \\
\hline 14 & Catalăo (GO) & INMET & 45 & Ponte BR 153/Prata (MG) & ANA \\
\hline 15 & Comendador Gomes (MG) & ANA & 46 & Ponte Joåo Candido/Patrocinio (MG) & ANA \\
\hline 16 & Coromandel (MG) & ANA & 47 & Pratinha (MG) & ANA \\
\hline 17 & Delfinópolis (MG) & ANA & 48 & Presidente Olegário (MG) & ANA \\
\hline 18 & Desemboque Sacramento (MG) & ANA & 49 & Quirmópolis (GO) & ANA \\
\hline 19 & Estrela do Sul (MG) & ANA & 50 & Santana de Patos/Patos de Mmas (MG) & ANA \\
\hline 20 & Fazenda Ajudas/Bambui (MG) & ANA & 51 & São Francisco de Sales (MG) & ANA \\
\hline 21 & Fazenda Aliança Goiatuba (GO) & ANA & 52 & Săo Gonçalo do Abaeté (MG) & ANA \\
\hline 22 & Fazenda Paraiso/Prata (MG) & ANA & 53 & Săo Gotardo (MG) & ANA \\
\hline 23 & Fazenda Săo Domingos/Catalăo (GO) & ANA & 54 & Selvíria (MS) & ANA \\
\hline 24 & Femandópolis (SP) & ANA & 55 & Serra do Salitre (MG) & ANA \\
\hline 25 & Fronteira (MG) & ANA & 56 & Tapira (MG) & ANA \\
\hline 26 & Guimarânia (MG) & ANA & 57 & Tupaciguara (MG) & ANA \\
\hline 27 & Gurinhată (MG) & ANA & 58 & Uberaba (MG) & INMET \\
\hline 28 & $\mathrm{lbia}(\mathrm{MG})$ & ANA & 59 & Uberländia (MG) & INMET \\
\hline 29 & Igarapava (SP) & ANA & 60 & Vazante (MG) & ANA \\
\hline 30 & Irá de Mimas (MG) & ANA & 61 & Verissimo (MG) & ANA \\
\hline 31 & Ifiguapira Uberaba (MG) & ANA & 62 & Zelândia Santa Juliana (MG) & ANA \\
\hline
\end{tabular}

Mapa 2 - Estações climatológicas e pluviômetros utilizados na área de estudo. Fonte: INMET/ANA. 
Os dados do algoritmo CHELSA - Climatologies at high resolution for the earth's land surface areas (Climatologia em alta resolução para as áreas terrestres da Terra), elaborado por Karger et al (2017), baseia-se em um downscaling estatístico da temperatura atmosférica de reanálise climática ERAInterim, e serviram de base para a elaboração do mapa de temperatura média do mês mais frio. Fazendo uma comparação dos dados derivados de temperatura do algoritmo CHELSA com outros produtos de alta resolução e com resolução temporal sobreposta como o Spectroradiômetro de Imagem de Resolução Moderada (MODIS), os dados climatológicos da CHELSA têm uma precisão semelhante, e podem ser usados para áreas onde a cobertura de estações meteorológicas é escassa. Para testar o algoritmo, foram feitas comparações com dados de temperatura média mensal de 88 estações do INMET espalhadas por todas as regiões do país. Em mais de $80 \%$ das análises, a diferença da temperatura média mensal foi menor que $1^{\circ} \mathrm{C}$; e em quase $50 \%$ menor que $0,5^{\circ} \mathrm{C}$. Esse erro foi considerado aceitável (Novais \& Brito, 2017).

Os valores de temperatura e precipitação foram inseridos numa planilha de balanço hídrico (BH) elaborada por Sentelhas et al (1998), onde foram calculadas a ETP e a quantidade de meses secos, parâmetros necessários para a subdivisão das primeiras hierarquias na classificação climática. Foi adotado o valor de $100 \mathrm{~mm}$ para a Capacidade de Água Disponível no solo (CAD), pois para fins climatológicos e de caracterização da disponibilidade hídrica regional é muito comum a adoção de valores de CAD variando de 75 a $125 \mathrm{~mm}$ (CARVALHO et al., 2008).

No gráfico a seguir (Figura 1), é mostrado um exemplo do cálculo do $\mathrm{BH}$ em Uberaba, pode-se notar a diferença entre a precipitação e a ETP no meio do ano, totalizando seis meses de déficit hídrico. 


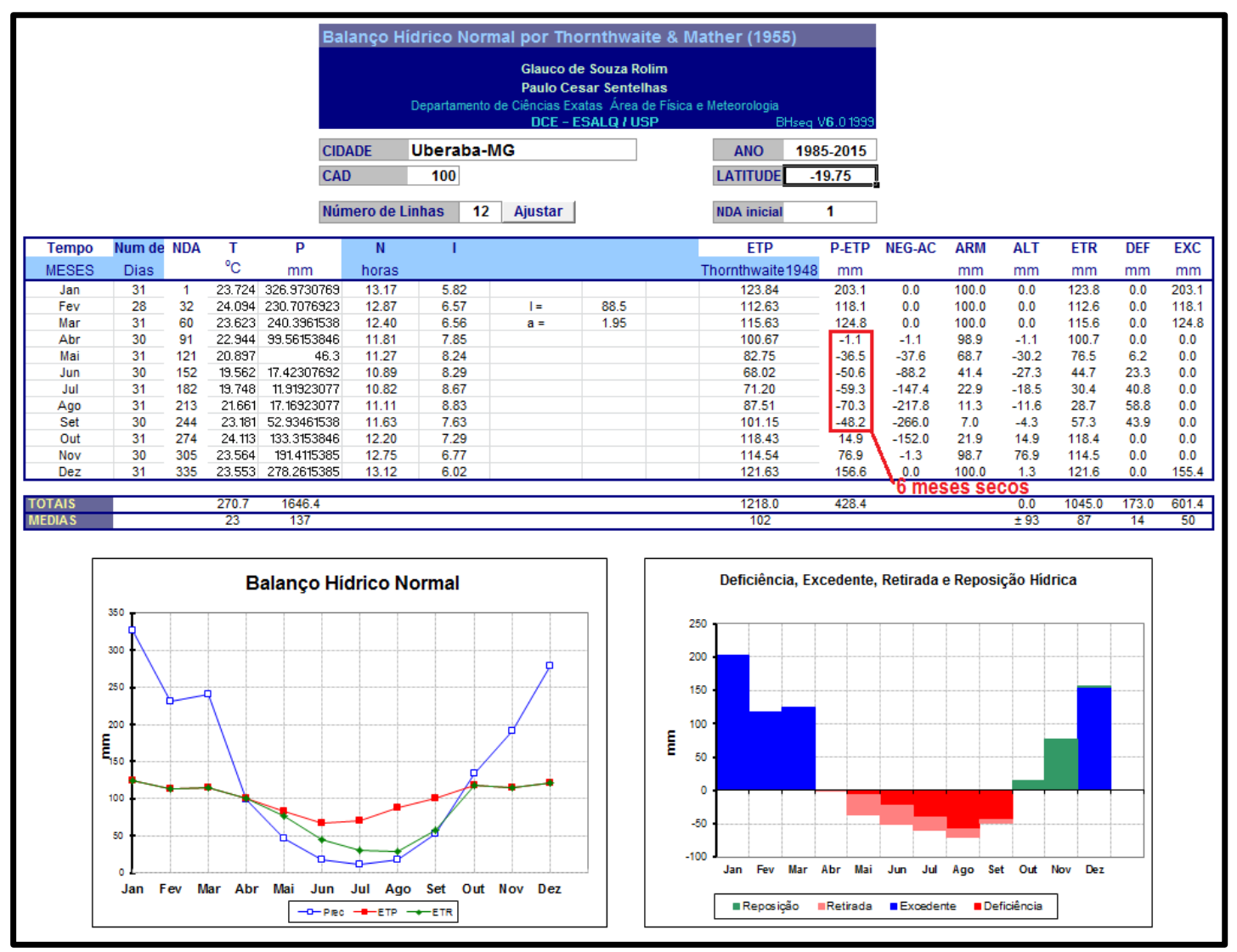

Figura 1 - Extrato do balanço hídrico para a cidade de Uberaba (MG). Dados de 19852015.

\section{RESULTADOS E DISCUSSÕES}

A TMMMF é um parâmetro elementar para a subdivisão climática desse trabalho, e a sua distribuição é apresentada no Mapa 3. Junho é considerado o mês mais frio na maior parte da área de estudo. No extremo sudeste da mesorregião o mês mais frio é julho.

A TMMMF tem seu maior valor no vale do rio Paranaíba, entre Araporã e Santa Vitória, com mais de $22^{\circ} \mathrm{C}$. A elevação do terreno, de oeste para leste, provoca um gradiente térmico responsável pela diminuição das temperaturas, sobretudo sob o domínio do Anticiclone Subtropical do Atlântico Sul (ASAS). No centro-nordeste a TMMMF fica entre $18^{\circ}$ e $20^{\circ} \mathrm{C}$. No planalto de Araxá e serras do Alto Paranaíba, a TMMMF fica entre $16^{\circ}$ e $18^{\circ} \mathrm{C}$, portanto o domínio climático nessas áreas muda de Tropical para Tropical Ameno. Nas terras mais altas do planalto de Araxá (chapadão da Zagaia) e na serra da Canastra (Sacramento), estão os menores valores de TMMMF, entre $14^{\circ}$ e $16^{\circ} \mathrm{C}$. Nos locais com TMMMF abaixo de $15^{\circ} \mathrm{C}$ o domínio é o Subtropical (Mapa 3) e correlaciona com pelo menos um dia de geada nesse mês. 


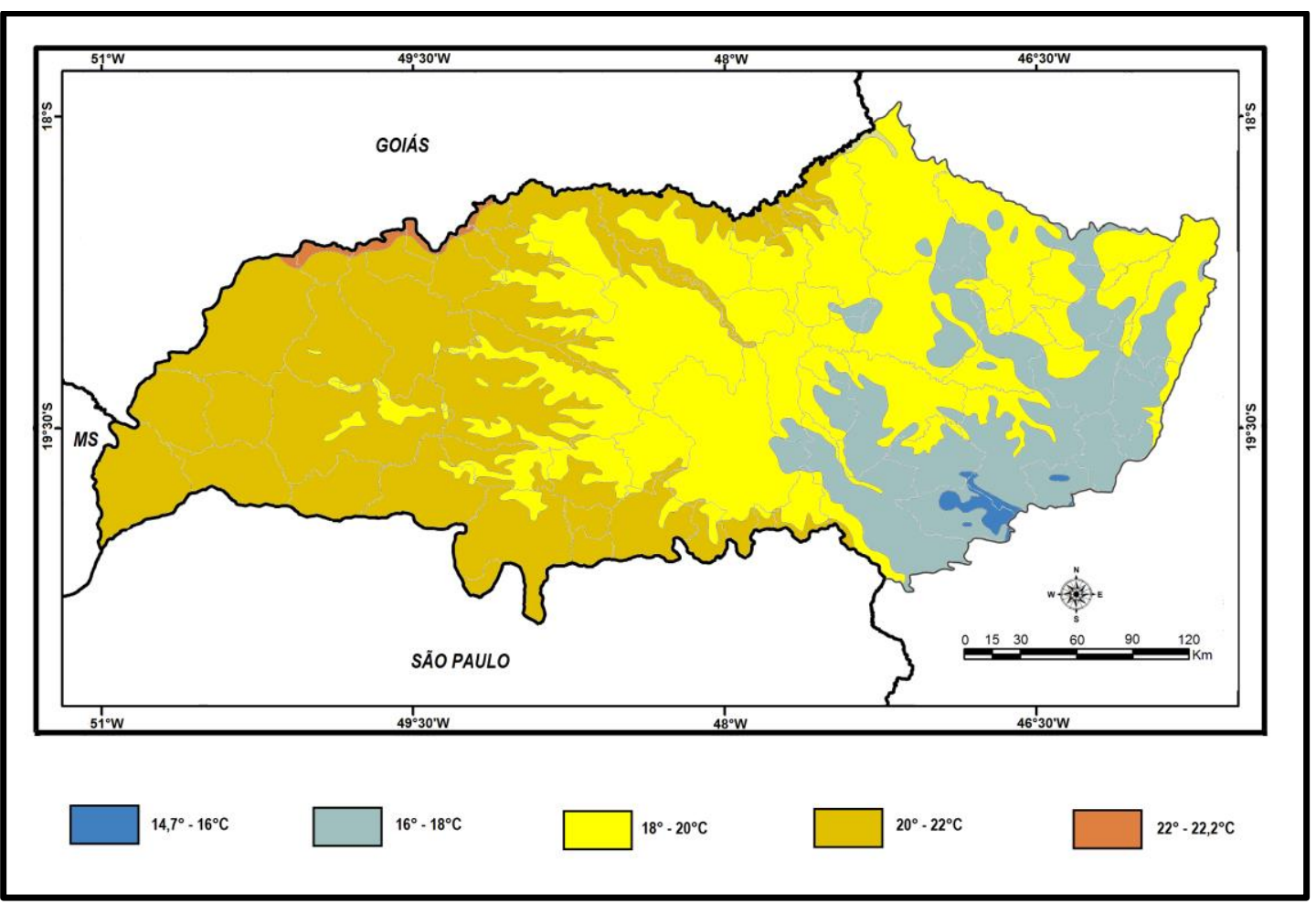

Mapa 3 - Temperatura média do mês mais frio (TMMMF) no Triângulo Mineiro/Alto Paranaíba. Fonte: CHELSA e INMET.

Como é mostrado no Mapa 4, a precipitação média anual é menor na região do Pontal do Triângulo, com valores entre $1300 \mathrm{~mm}$ e $1450 \mathrm{~mm}$. Na maioria da microrregião de Patrocínio, incluindo o vale do rio Quebra-Anzol e represa de Nova Ponte, a precipitação também fica em torno dos 1350 mm/ano. Os maiores valores pluviométricos anuais estão localizados no sul do município de Perdizes, limite com Santa Juliana, Sacramento e Araxá, com mais de 1750 $\mathrm{mm}$; chegando a quase $1900 \mathrm{~mm}$ em Zelândia (Santa Juliana), valor que provoca um excedente hídrico de mais de $200 \mathrm{~mm}$ em dezembro e janeiro.

Convém destacar que tais valores pluviométricos anuais são caracterizados por uma variabilidade sazonal em um período muito chuvoso e outro seco, típico da climatologia tropical. Reboita et al. (2010; 2012) esclarecem que durante o verão austral, o forte aquecimento radiativo da superfície permite o desenvolvimento de atividades convectivas. Parte desses sistemas convectivos está relacionada à dinâmica do escoamento dos Jatos de Baixos Níveis (JBN), vindos da Amazônia, os quais podem integrar a circulação do ASAS, promovendo aumento de nebulosidade e de precipitações intensas na região de estudo (Zona de Convergência de Umidade - ZCOU e Zona de Convergência do Atlântico Sul - ZCAS).

Por outro lado, durante o inverno austral, a rápida passagem das frentes frias (linhas de instabilidade) e a longa permanência do ASAS sobre a região central do país dificulta a formação de sistemas convectivos contribuindo para a redução dos níveis de umidade do ar sobre a área de estudo. Logo, a 
permanência desse sistema acaba por influenciar na duração do período seco da tropicalidade regional (em média, de abril a setembro).

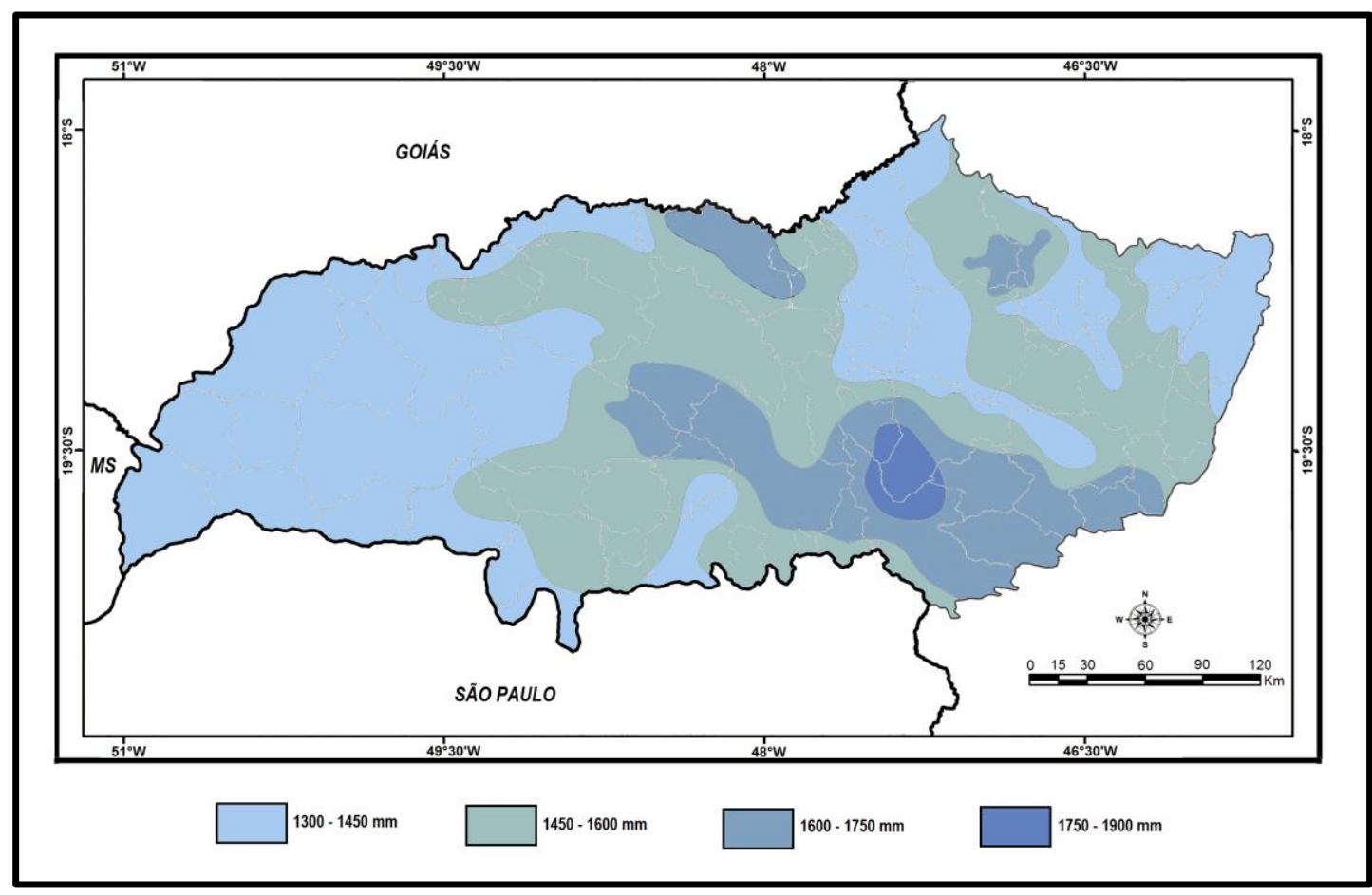

Mapa 4 - Pluviosidade média anual no Triângulo Mineiro/Alto Paranaíba. Fonte: ANA e INMET.

A quantidade de meses secos é influenciada principalmente pelos valores de temperatura média mensal e quantidade de precipitação pluviométrica, averiguadas na planilha de balanço hídrico.

O trabalho de Sanches et al. (2017) procurou demonstrar que existe uma tendência de redução das precipitações nos meses de outubro, bem como de elevação das temperaturas (máximas, médias e mínimas) na região do Triângulo Mineiro, que podem ser consideradas significativas para mudanças climáticas. Os autores também demonstraram por meio de teste de análise de covariância (ANCOVA) que existe uma forte relação entre o aumento das temperaturas nos meses de outubro com a redução nos valores de pluviosidade e de umidade relativa.

Sanches et al. (2017) ainda afirmam que a redução das chuvas e da umidade relativa nos meses de outubro, juntamente com o aumento das temperaturas (máxima, média e mínima) possuem relação direta com a permanência de sistemas atmosféricos tropicais sobre o continente brasileiro, provendo um fenômeno descrito por Ambrizzi et al. (2009) e Scaife (2017) como Bloqueio Atmosférico, o qual impede a penetração e o avanço dos sistemas polares e de suas Linhas de Instabilidade frontais.

Os locais de menor altitude e maior temperatura favorecem a maior quantidade de meses secos. Já nos locais onde a temperatura média mensal é 
mais baixa e também onde a precipitação é maior, os valores ajudam a aumentar o excedente hídrico mensal, diminuindo os meses onde a evapotranspiração é maior.

O Mapa 5 demonstra que nos vales dos rios Paranaíba, Grande e Araguari (bacia do rio Paraná), e nos vales dos rios Abaeté, Borrachudo e Indaiá (bacia do rio São Francisco), a quantidade de meses secos atinge sete meses do ano, ou seja, de abril a outubro onde a evapotranspiração potencial é maior que a quantidade de precipitação pluviométrica. Já nos patamares dos chapadões do Triângulo Mineiro/Alto Paranaíba a quantidade de meses secos diminui para seis (de abril a setembro). Nesses dois exemplos, o subdomínio climático é semiseco. Verifica-se assim que onde a temperatura média do mês diminui, a quantidade de meses secos também diminui. Nos chapadões do Triângulo Mineiro, Alto Paranaíba e planalto de Araxá os meses secos são cinco, geralmente maio, junho, julho, agosto e setembro. A serra da Canastra, no município de Sacramento, e as terras mais altas do planalto de Araxá possuem quatro meses secos somente (de maio a agosto).

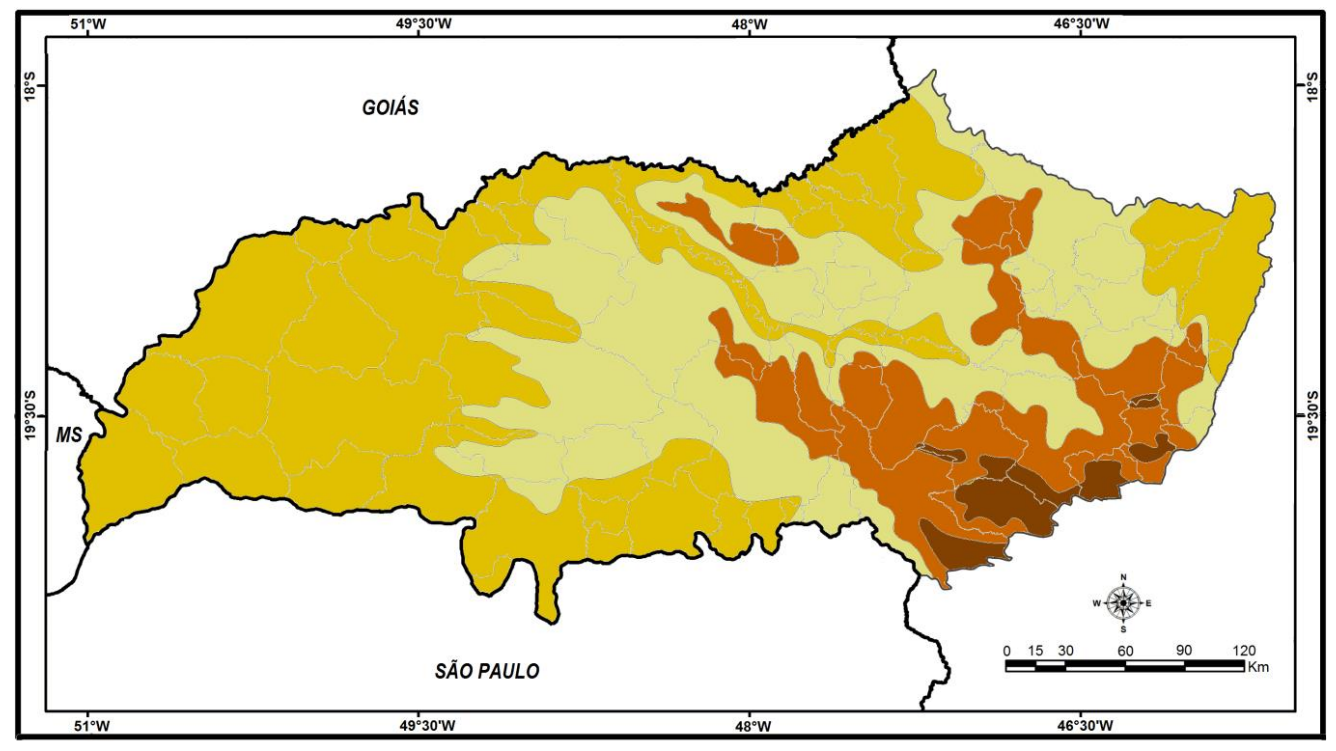

QUATRO MESES SECOS

Mapa 5 - Quantidade de meses secos no Triângulo Mineiro/Alto Paranaíba. Fonte: CHELSA, INMET e ANA.

Os climas zonais identificados na mesorregião do Triângulo Mineiro/Alto Paranaíba foram: o Quente e o Moderado, sendo que o segundo ocupa apenas as terras mais altas do Chapadão da Zagaia (em Tapira) e parte da Serra da Canastra em Sacramento.

Os Domínios Climáticos encontrados na área de estudo são: Tropical, Tropical Ameno e Subtropical. 
Nos domínios climáticos Tropical e Tropical Ameno não há influência da Zona de Convergência Intertropical (ZCIT), típica dos domínios equatoriais, mas tem a presença das ZCOU e ZCAS (no caso brasileiro). O Tropical Ameno possui TMMMF mais baixa, entre $15^{\circ}$ e $18^{\circ} \mathrm{C}$ (equivalente ao clima Cwa de Koeppen), e o Tropical de $18^{\circ} \mathrm{C}$ a $22,5^{\circ} \mathrm{C}$. No domínio climático Subtropical, a entrada das massas polares no inverno, logo após a passagem das frentes frias, faz a TMMMF cair abaixo de $15^{\circ} \mathrm{C}$, provocando geadas em pelo menos um dia no ano.

O Mapa 6 apresenta os domínios climáticos (juntamente com seus subdomínios) que aparecem na área de estudo, ou seja, Tropical, Tropical Ameno e Subtropical.

O domínio climático Tropical é o mais extenso e recebe influência das ZCOU e ZCAS nos meses mais úmidos e quentes (de outubro a março). Seu mês mais frio possui temperatura média acima de $18^{\circ} \mathrm{C}$, mas não ultrapassa os $22,5^{\circ} \mathrm{C}$. Esse domínio ocupa praticamente todo o Triângulo Mineiro, e avança pelas terras mais baixas do Alto Paranaíba.

O domínio climático Tropical Ameno tem influência da altitude na região, onde sua TMMMF fica entre $15^{\circ}$ e $18^{\circ} \mathrm{C}$. Compreende o planalto de Araxá e regiões serranas do Alto Paranaíba.

No chapadão da Zagaia e na serra da Canastra (Sacramento) o domínio climático é o Subtropical, possuindo as menores TMMMF, abaixo de $15^{\circ} \mathrm{C}$. Nesses locais, a geada é anual, e as temperaturas mínimas absolutas negativas são comuns.

Os subdomínios climáticos identificados no Triângulo Mineiro/Alto Paranaíba são: semiúmido (4 a 5 meses secos) e semiseco ( 6 a 7 meses secos); com influência total da evapotranspiração. O subdomínio semiúmido é encontrado nos chapadões do Triângulo Mineiro, planalto de Araxá, Alto Paranaíba e serra da Canastra; e o subdomínio semiseco no restante da área de estudo, inclusive na região do chapadão de Monte Carmelo a Iraí de Minas onde a precipitação média anual é mais baixa que seu entorno (Mapa 6). 


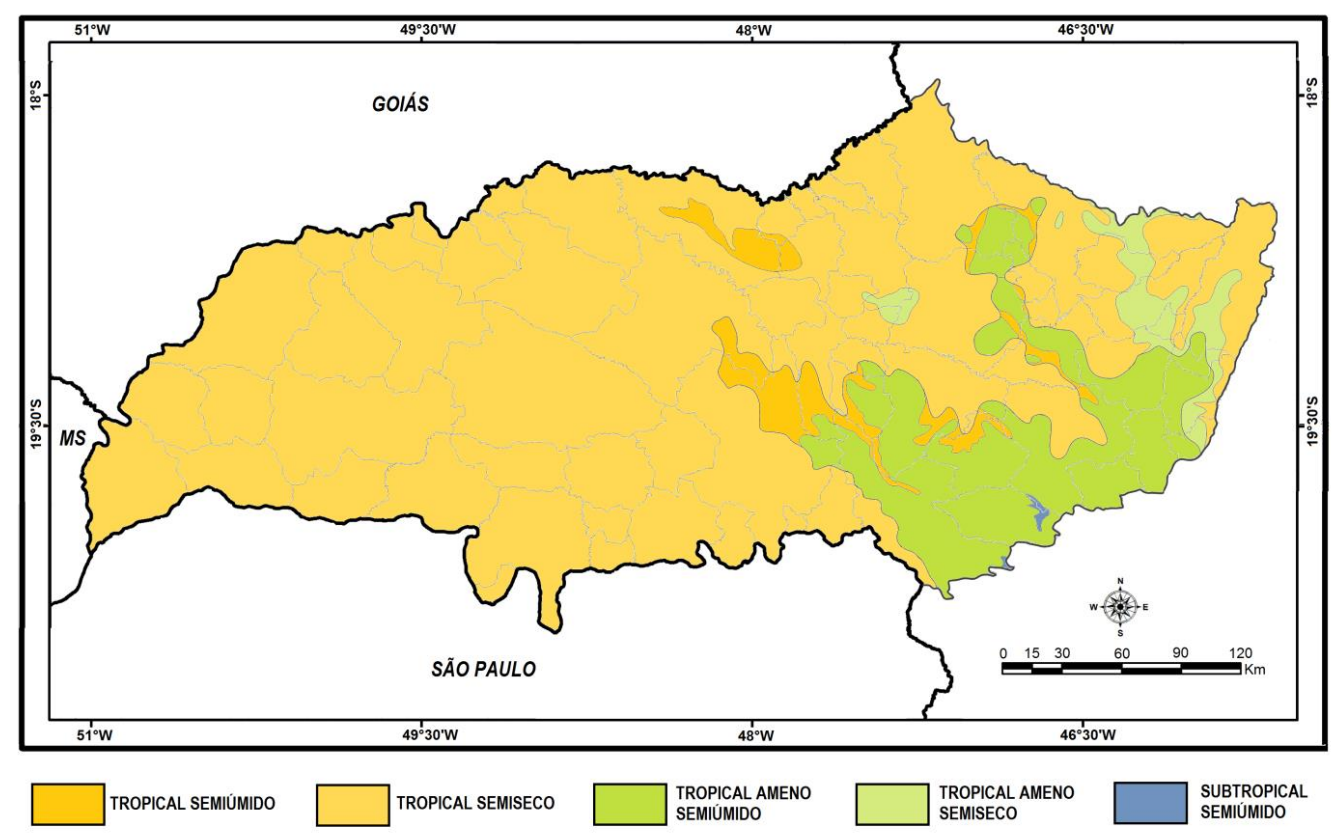

Mapa 6 - Domínios e subdomínios climáticos no Triângulo Mineiro/Alto Paranaíba.

Para localizar as unidades climáticas dentro dos domínios e subdomínios, são utilizados os tipos e subtipos. Os tipos climáticos dos subdomínios Tropical semiúmido e Tropical semiseco ocorrem no território brasileiro espalhados por Mato Grosso, Goiás e Tocantins (tipo central), Nordeste, região litorânea e região meridional (área de maior incursão de sistemas meteorológicos como frentes frias e geadas esporádicas). Os tipos climáticos do domínio Subtropical no Brasil distribuem-se pela região ao sul do Trópico de Capricórnio (meridional) e ao norte do mesmo (setentrional).

Na mesorregião estudada o tipo meridional aparece nos subdomínios Tropical semiúmido, Tropical semiseco, Tropical Ameno semiúmido e Tropical Ameno semiseco. No subdomínio Subtropical semiúmido, o tipo é o setentrional, por estar ao norte do Trópico de Capricórnio.

A última hierarquia climática desse trabalho consiste nos subtipos (Mapa 7). Eles foram definidos pela sua localização dentro do estado de Minas Gerais, mas principalmente, dentro da mesorregião do Triângulo Mineiro/Alto Paranaíba, e são apresentados a seguir. 


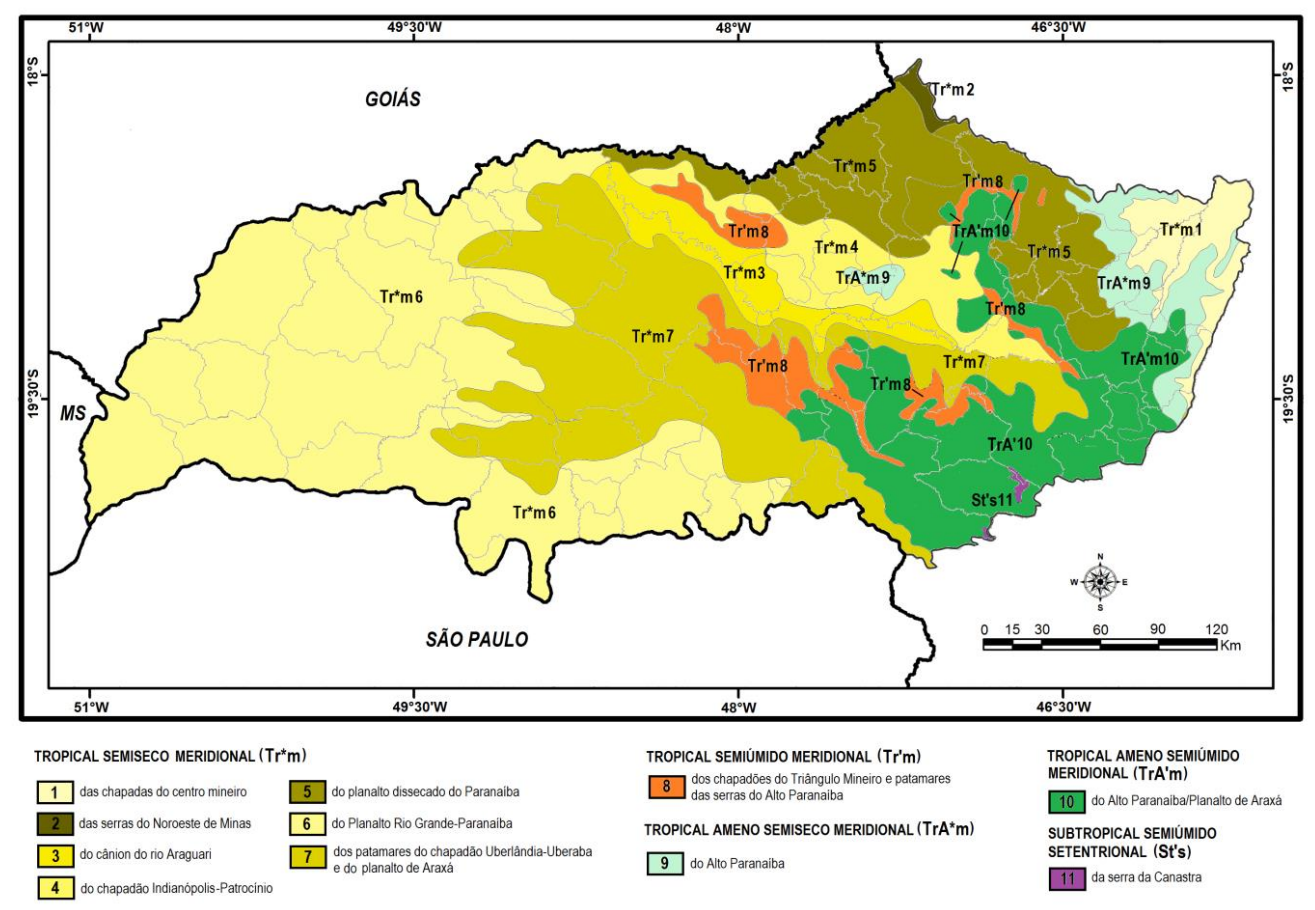

Mapa 7 - Unidades climáticas do Triângulo Mineiro/Alto Paranaíba.

\section{Tropical semiseco meridional das chapadas do centro mineiro}

Esta unidade abrange as áreas localizadas nos vales dos rios Borrachudo, Abaeté e Indaiá, no extremo leste da mesorregião. Com altimetrias variando de 625 a 1000 metros na mesorregião.

De clima zonal quente, pertence ao domínio Tropical, com influência de ZCOUs e ZCAS no período chuvoso (novembro-março) e ASAS no período seco, sendo seu subdomínio o semiseco, com sete meses secos (abril a outubro). 0 tipo climático é o meridional, com incursões de frentes frias periódicas e formação muito rara de geadas (uma a cada 30 anos).

A temperatura média do mês mais frio - TMMMF (junho) varia de $18,5^{\circ}$ a $20^{\circ} \mathrm{C}$, com precipitação pluviométrica anual entre 1350 e $1450 \mathrm{~mm}$.

\section{Tropical semiseco meridional das serras do Noroeste de Minas}

Este fragmento de subtipo climático aparece na mesorregião somente ao norte do município de Coromandel. É uma região serrana que se prolonga pelos municípios da mesorregião do Noroeste de Minas, e também faz limite com 0 estado de Goiás, tornando-se o planalto Central. Possui altimetrias entre 850 e 1000 metros.

De clima zonal quente, pertence ao domínio Tropical, com influência de ZCOUs e ZCAS no período chuvoso (novembro-março). Seu subdomínio é o semiseco, com seis meses secos (abril a setembro) influenciados pelo ASAS. O 
tipo climático é o meridional, com incursões de frentes frias periódicas e formação muito rara de geadas (uma a cada 30 anos).

A TMMMF (junho) varia de $18,5^{\circ}$ a $19,5^{\circ} \mathrm{C}$, com precipitação pluviométrica anual entre 1350 e $1500 \mathrm{~mm}$.

\section{Tropical semiseco meridional do cânion do rio Araguari}

Esta unidade abrange todo cânion constituído pelo rio Araguari, no centro da mesorregião. Possui um relevo muito dissecado com vales bem talhados e altimetrias entre 500 e 1000 metros.

De clima zonal quente, pertence ao domínio Tropical, com influência de ZCOUs e ZCAS no período chuvoso (novembro-março). Seu subdomínio é o semiseco, com sete meses secos (abril a outubro). O tipo climático é o meridional, com incursões de frentes frias periódicas, decorrentes do ASAS e com formação rara de geadas (uma a cada 5 anos).

A TMMMF (junho) fica entre $18^{\circ}$ e $21,5^{\circ} \mathrm{C}$, com a precipitação pluviométrica anual variando de 1350 e $1600 \mathrm{~mm}$.

\section{Tropical semiseco meridional do chapadão Indianópolis-Patrocínio}

Unidade climática que cerca os topos mais altos do grande chapadão de Araguari a Patrocínio, formando patamares entre Indianópolis e Patrocínio. Possui altimetrias variando de 800 a 1000 metros.

De clima zonal quente, pertence ao domínio Tropical, com influência de ZCOUs e ZCAS no período chuvoso (novembro-março). Seu subdomínio é o semiseco, de seis a sete meses secos (abril a setembro-outubro). O tipo climático é o meridional, com incursões de frentes frias periódicas (ASAS) e formação rara de geadas (uma a cada 5 anos).

A TMMMF (junho) varia de $18^{\circ}$ a $19,5^{\circ} \mathrm{C}$, com precipitação pluviométrica anual de 1350 a $1650 \mathrm{~mm}$.

\section{Tropical semiseco meridional do planalto dissecado do Paranaíba}

Essa unidade está presente desde a borda norte do chapadão de Araguari a Patrocínio e no vale do rio Paranaíba desde a montante da represa de Itumbiara até próximo de suas nascentes. Relevo caracterizado por vales intensamente dissecados. Possui altimetrias variando de 500 a 900 metros.

Também possui um clima zonal quente, e pertence ao domínio tropical, com influência de ZCOUs e ZCAS no período chuvoso (novembro-março). Seu subdomínio é o semiseco, de seis a sete meses secos (abril a setembro-outubro) fortemente influenciado pelo ASAS. O tipo climático é o meridional, com incursões de frentes frias periódicas e formação rara de geadas (uma a cada 5 anos).

A TMMMF (junho) varia de $18^{\circ}$ a $22^{\circ} \mathrm{C}$, com precipitação pluviométrica anual de 1400 a $1650 \mathrm{~mm}$. 


\section{Tropical semiseco meridional do planalto Rio Grande-Paranaíba}

Maior unidade climática da mesorregião abrangendo os baixos vales dos rios Grande e Paranaíba, até a sua confluência. Engloba grande parte do Pontal do Triângulo, inclusive os relevos residuais no limite com os patamares dos chapadões do Triângulo Mineiro. Possui altimetrias que variam de 350 a 700 metros.

De clima zonal quente, pertence ao domínio Tropical, com influência de ZCOUs e ZCAS no período chuvoso (novembro-março). Seu subdomínio é o semiseco, com sete meses secos (abril a outubro). O tipo climático é o meridional, com incursões de frentes frias periódicas, instalação do ASAS e formação muito rara de geadas (uma a cada 30 anos).

A TMMMF (junho) varia de $20^{\circ}$ a $22,5^{\circ} \mathrm{C}$ (unidade climática mais quente da mesorregião), com precipitação pluviométrica anual entre 1350 e 1500 mm.

\section{Tropical semiseco meridional dos patamares do chapadão Uberlândia- Uberaba e do planalto de Araxá}

Essa unidade climática faz a transição dos baixos vales dos rios GrandeParanaíba, para as áreas mais elevadas dos chapadões na mesorregião. Possui um relevo medianamente dissecado, com altimetrias variando de 600 a 950 metros.

Fica dentro do clima zonal quente, e pertence ao domínio Tropical, com influência de ZCOUs e ZCAS no período chuvoso (novembro-março). Seu subdomínio é o semiseco, com seis meses secos (abril a setembro). O tipo climático é o meridional, com incursões de frentes frias periódicas, instalação do ASAS e formação rara de geadas (uma a cada 5 anos).

A TMMMF acontece em junho, e varia de $18^{\circ}$ a $20^{\circ} \mathrm{C}$, com precipitação pluviométrica anual de 1350 a $1600 \mathrm{~mm}$.

\section{Tropical semiúmido meridional dos chapadões do Triângulo Mineiro e patamares das serras do Alto Paranaíba}

Esse é o único subtipo climático pertencente ao subdomínio Tropical semiúmido na mesorregião estudada. Abrange dois chapadões no Triângulo Mineiro, o de Araguari e as terras mais altas entre Uberlândia e Uberaba, juntamente com os últimos patamares do relevo até as serras do Alto Paranaíba e também manchas no planalto de Araxá. O relevo é caracterizado por topos planos às vezes limitados por escarpas abruptas. Possui altimetrias variando de 950 a 1100 metros.

Está incluso no clima zonal quente, pertencendo ao domínio Tropical, com influência de ZCOUs e ZCAS no período chuvoso (novembro-março). Seu subdomínio é o semiúmido, com cinco meses secos (maio a setembro). O tipo climático é o meridional, com incursões de frentes frias periódicas (ASAS) e formação rara de geadas (uma a cada 5 anos).

A TMMMF (junho) varia de $18^{\circ}$ a $19^{\circ} \mathrm{C}$, com precipitação pluviométrica anual de 1450 a $1900 \mathrm{~mm}$ (região de maior pluviosidade média da área de estudo). 


\section{Tropical Ameno semiseco meridional do Alto Paranaíba}

Essa unidade climática abrange o divisor de águas das bacias do Paranaíba e São Francisco, no leste da mesorregião, e também o topo do chapadão próximo a Celso Bueno (Patrocínio). Possui altimetrias variando de 1000 a 1150 metros.

Está incluso no clima zonal quente, pertencendo ao domínio Tropical Ameno, com influência de ZCOUs e ZCAS no período chuvoso (novembromarço). Seu subdomínio é o semiseco, com seis meses secos (abril a setembro) sob atuação do ASAS. O tipo climático é o meridional, com incursões de frentes frias periódicas e formação rara de geadas (uma a cada 5 anos).

A TMMMF (junho) varia de $17^{\circ}$ a $18^{\circ} \mathrm{C}$, com precipitação pluviométrica anual de 1350 a $1500 \mathrm{~mm}$.

\section{Tropical Ameno semiúmido meridional das serras do Alto Paranaíba e planalto de Araxá}

Unidade climática influenciada pelo resfriamento adiabático provocado pelas elevações das serras do Alto Paranaíba (Negra, do Salitre, etc.) e do planalto de Araxá. Possui um relevo intensamente dissecado, com altimetrias variando de 1050 a 1250 metros.

Fica dentro do clima zonal quente, e pertence ao domínio Tropical Ameno, com influência de ZCOUs e ZCAS no período chuvoso (novembromarço). Seu subdomínio é o semiúmido de quatro a cinco meses secos (maio a agosto-setembro). O tipo climático é o meridional, com incursões de frentes frias periódicas, permanência do ASAS e formação rara de geadas (uma a cada 5 anos).

A TMMMF acontece em junho (Alto Paranaíba) e em julho (planalto de Araxá), variando de $15,0^{\circ}$ a $17,5^{\circ} \mathrm{C}$, com precipitação pluviométrica anual de 1450 a $1750 \mathrm{~mm}$.

\section{Subtropical semiúmido setentrional da serra da Canastra}

Única unidade climática pertencente ao domínio Subtropical. Também influenciada pelo resfriamento adiabático provocado pelas elevações da serra da Canastra (no município de Sacramento), e chapadão da Zagaia (Tapira). Possui um relevo de topo plano cercado por escarpas abruptas, entre altimetrias que variam de 1250 a 1350 metros. São os locais mais altos do Triângulo Mineiro/Alto Paranaíba.

Pertence ao clima zonal moderado, e como citado anteriormente, está dentro do domínio Subtropical, com influência de ZCOUs e ZCAS no período chuvoso (novembro-março). Seu subdomínio é o semiúmido de quatro meses secos (maio a agosto). O tipo climático é o setentrional, pois se localiza ao norte do Trópico de Capricórnio. Frentes frias são periódicas devido a atuação do ASAS e com formação anual de geadas.

A TMMMF acontece em julho, e varia de $14,5^{\circ}$ a $15,0^{\circ} \mathrm{C}$, com precipitação pluviométrica anual de 1550 a $1600 \mathrm{~mm}$. 


\section{CONSIDERAÇÕES FINAIS}

As unidades climáticas identificadas nesse trabalho mostraram a importância dos sistemas meteorológicos que atuam sobre a região do Triângulo Mineiro, sobretudo, a atuação do Anticiclone Subtropical do Atlântico Sul (ASAS) e de sua dinâmica associada a formação das Zonas de Convergência de Umidade (ZCOU), da Zona de Convergência do Atlântico Sul (ZCAS), do papel do ASAS influenciando nas condições de ocorrência da Temperatura Média do Mês mais Frio (TMMMF), bem como na quantidade de meses secos para a sua delimitação.

O componente estrutural geomorfológico, fato diretamente ligado à dinâmica climática atual e pretérita, serviu para demarcar as menores unidades climáticas, demonstrando, claramente, o papel da superfície - topografia - e sua relação com os sistemas atmosféricos.

Nesse trabalho optou-se por subdividir as unidades até o nível de subtipos climáticos ampliando as tradicionais propostas de classificações climáticas, detalhando melhor seus compartimentos e subcompartimentos.

Por sua vez, caso a classificação adotasse os níveis escalares dos meso/topoclimas na mesorregião do Triângulo Mineiro/Alto Paranaíba, sua quantidade ultrapassaria os três dígitos, não podendo ser descritos em um artigo somente. Dessa forma, a partir da metodologia proposta, sugerimos o desenvolvimento de estudos específicos em nível de bacias hidrográficas intraregionais, sub-bacias e microbracias, por exemplo, para a elaboração de trabalhos para cada subdomínio, apresentando-os separadamente.

A definição das unidades climáticas do Triângulo Mineiro/Alto Paranaíba fornece importantes subsídios para novos estudos regionais em climatologia (climatologia de detalhe), como a localização de meso/topoclimas nos subtipos.

Esse novo sistema de classificação climática é aperfeiçoado, devido a grande quantidade de fonte de dados históricos utilizados, os recursos técnicos para sua proposição (ambiente SIG) podendo ser usado em análises ambientais, didáticas e agrícolas em nível detalhado de escalas espaciais.

\section{REFERÊNCIAS}

AMBRIZZI, T.; MARQUES, R.; NASCIMENTO, E. Bloqueios atmosféricos. In: CAVALCANTI, I.F.A.; FERREIRA, N.J.; SILVA DIAS, A.F.; SILVA, M.G.A.J. Tempo e clima no Brasil. São Paulo: Oficina de Textos, 2009.

ASSAD, E.D. [et al]. Impacto das mudanças climáticas no zoneamento agroclimático do café no Brasil. Brasília: Empresa Brasileira de Pesquisa Agropecuária (EMBRAPA), 2004.

BACCARO, C.A.D.; FERREIRA, I.V.; ROCHA, M.R.; RODRIGUES, S.C. Mapa geomorfológico do Triângulo Mineiro: uma abordagem morfoestruturalescultural. Revista Sociedade \& Natureza. Uberlândia, 13 (25): 115-127, 2001.

CARVALHO, L.G.; OLIVEIRA, M.S.; ALVES, M.C.; VIANELLO, R.L; SEDIYAMA, G.C; NETO, P.C.; DANTAS, A.A.A; Clima. In: SCOLFORO, J.R.S.; CARVALHO, L.M.T.; OLIVEIRA, A.D. Zoneamento ecológico-econômico do Estado de Minas Gerais: componentes geofísico e biótico. Lavras: Editora UFLA, 2008. 
CAVALCANTI, I.F.A.; FERREIRA, N.J.; DA SILVA, M.G.A.; DIAS, M.A.F.S. Tempo e clima no Brasil. São Paulo: Oficina de Textos, 2009.

FUENTES, M.V. Dinâmica e Padrões da precipitação de neve no sul do Brasil. Tese de doutorado apresentada ao Instituto de Geociências da Universidade Federal do Rio Grande do Sul. Porto Alegre, 2009.

KARGER, D.N.; CONRAD, O.; BÖHNER, J.; KAWOHL, T.; KREFT, H.; SORIAAUZA, R.W.; ZIMMERMANN, N.E.; LINDER, H.P.; KESSLER, M. Dados de Climatologia em alta resolução para as áreas terrestres. In: Dryad Digital.Repository. 2017. https://doi.org/10.5061/dryad.kd1d4.

KOEPPEN, W. Climatologia: con un studio de los climas de la tierra. $1^{\circ}$ edición em español. Fundo de Cultura Económica: México, 1948.

LEITE, E. P. F.; Silva, J. S.; Gomes, G. S. Obtenção de modelo numérico do terreno de alta resolução utilizando o interpolador Spline com tensão regularizada. In: Congresso de Pesquisa e Inovação da Rede Norte Nordeste de Educação Tecnológica - CONNEPI João Pessoa, 2007.

MARCUZZO, F.F.N.; CARDOSO, M.R.D.; MELLO, L.T.A. Uso dos Métodos de Krigagem e Spline de Tensão no Mapeamento de Chuvas na Região Metropolitana de Goiânia e Seu Entorno. In: II Simpósio Internacional Caminhos Atuais da Cartografia na Geografia. Anais... São Paulo: EDUSP. 2010.

MENDONÇA, F. Aquecimento global e saúde: uma perspectiva geográfica notas introdutórias. Revista Terra Livre, São Paulo, no 20, p. 205-221, 2003.

NOVAIS, G.T.; BRITO, J.L.S. Avanço do domínio climático subtropical para o norte do Trópico de Capricórnio: um exemplo da serra dos Órgãos (RJ). In: VII Simpósio Internacional de Climatologia. Anais. Petrópolis, 2017.

NOVAIS, G.T. Distribuição média dos Climas Zonais no Globo: estudos preliminares de uma nova classificação climática. Revista Brasileira de Geografia Física. v. 10. n.5. p.1614-1623. Recife, 2017.

NOVAIS, G.T. Unidades climáticas no domínio do Cerrado: estudos preliminares de uma nova classificação climática. In: XII Simpósio Brasileiro de Climatologia Geográfica. Anais. Goiânia, 2016. p.2278-2289.

REBOITA, M.S.; GAN, M.A.; ROCHA, R.P.; AMBRIZZI, T. Regimes de precipitação na América do Sul: uma revisão bibliográfica. Revista Brasileira de Meteorologia, v.25, n.2, 185-204, 2010.

REBOITA, M.S.; KRUSCHE, N.; AMBRIZZI, T.; ROCHA, R.P. Entendendo o Tempo e o Clima na América do Sul. Terra e Didática, 8(1): 34-50, 2012.

SANCHES, F.; SILVA, R.V.; FERREIRA, R.V.; CAMPOS, C.A.A. Climate change in the Triângulo Mineiro region - Brazil. Revista Brasileira de Climatologia, v. 1, p. 570-587, 2017.

SCAIFE, A.A. Meteorologia: 50 conceitos e fenômenos fundamentais explicados de forma clara e rápida. São Paulo: Publifolha, 2017.

SENTELHAS, P.C.; ROLIM, G.S.; BARBIERI, V. Planilhas no ambiente EXCEL TM para os cálculos de balanços hídricos: normal, sequencial, de cultura e de produtividade real e potencial. Revista Brasileira de Agrometeorologia, Santa Maria, v. 6, n.1, p133-137, 1998. 
STRAHLER, A. N. Geografía Física. Omega: Barcelona, 1989.

TERASSI, P.M.B.; SILVEIRA, H. Aplicação de sistemas de classificação climática para a bacia hidrográfica do rio Pirapó-PR. Revista Formação, Volume 1, Número 20, Ano 2013 - p. 111-12, Presidente Prudente, 2013. 